\title{
オートチューニングファジィフィルタによる 加速度コントローラの構成法
}

論 文

$\begin{array}{llll}\text { 正員大 石 } & \text { 潔 (大阪工大) } \\ \text { 正貝 土 川 浩 史 (大阪工大) }\end{array}$

Design Method of Acceleration Controller Besed on Auto-tuning Fuzzy Filter

Kiyoshi Ohishi, Member, Hiroshi Tsuchikawa, Member (Osaka Institute of Technology)

It has been reported that the acceleration control method realizes a fine and fast motion control. The acceleration control method has an ability to suppress the effects of dynamical nonlinearities rapidly. Moreover, the acceleration control method has an accurate output response for each motion reference. However, when the conventional acceleration control system is designed, it is often difficult to define both its nominal parameters and its frequency characteristics systematically.

This paper proposes the new model following acceleration control system using the auto.tuning fuzzy filter. The structure of the proposed system has no nominal mechanical parameter of actuator. Its frequency characteristics is determined by the auto-tuning fuzzy filter. This fuzzy filter is constructed by the new auto-tuning algorithm based on the simplex design method. Therefore, the proposed acceleration control system is designed automatically, and it realizes a fine motion control easily.

キーワード：加速度制缻，ファジィ制御，モーションコントロール

\section{1.まえがき}

ロボット制御の分野において，高精度なモーション 制御を行うために、アクチュエータの高情能な制御系 の夷晲が望まれている。ロボットの各関節を駆動する アクチュエータには、モーション制微の際に摩摖力・ 干涉力・慣性力・重力などの様々な外力加的加される のて、アクチュエータを駆動する制御系は外力の影掣 を瞬時に補供する必要がある。そのためにこれまて 外乱オブザーバやモデル追従加速度制御系などによっ て加速度コントローラを構成し,この加速度コントロ ーラに基づくロボットマニピュレータの高性能なモー ション制御法が提案されてきだ(1)円3)。加速度コント ローラは, ロポットマニピュレータの各関節のアクチ ュエータを加速度指令で駆動させるのて, マニピュレ

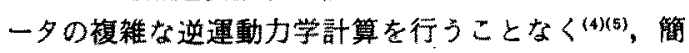
单にロバストなモーション制御を実現させることがで きる。

しかしながら，徉来の加速度コントローラては, 制
御対象であるロボットマニビュレータの各関節のアク チュエータの梏诰や，パラメータのノミナル值をあら かじめ知っておく必要がある。また，加速度コントロ 一ラの応答性能を決めるとき，設棓者はこのための試 行錯誤的作樊と経鞛的知識をある程度必要になる。こ のため, 加速度コントローラの構成法がかかっていて もそれを実現するときに煩雑な作業をある程度伴う ことになる。

そこで本論文ては，従来のモデル追従加速度制御系 にオートチューニングファジフィル夕を付加するこ

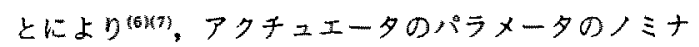
ル值を一切必要とせずに，所望の応答特性をもつ加速 度コントローラを自動的に実現する方法を提案する。 提案する加速度コントローラは，モデル追従加速度制 御系の規範モデルに理想的な加速度コントローラを採 用し、かつ加速盾コントローラの应答特性を洪定する 作業をすべてオートチューニングファジィフィル夕に 集約させている。これより，制御刘象の構造やパラメ 一夕の情報をあら的知る必要がなく，更に試行錯 
誤的作業や経験的知識も要求されることもない。

本諭文では，1自由度マニピュレータによる実験と シミュレーションによって，提案する加速度コントロ ーラの構成法の有効性を確証している。

\section{2. ファジィフィルタを付加したモデル追従 加速度制御系}

加速度コントローラは, 図 1 に示すように積分器 2 個をカスケード結合した形で転成される。ロボットマ ニピュレータの各関節のアクチュエータが図10よう な加速度コントローラとして报えると、ロボットマニ ピュレータのモーション制御は加速度指令に基づいて 計画すればよくなる。この結果，口ボットマニピュレ 一タのモーション計画が簡単になり，かつ高性能な応 答結果が期待できることになる。

加速度コントローラをより簡筆に赛現するために, 規範モデルに理想的な加速度コントローラを採用した モデル追従加速度制御系を図20ように構成する。図 2 において，P(s) はロボットマニピュレータの関節 を駆動するアクチュエータである。ここでは、トルク 指令で駆動される DDモータを制御対象のアクチュ工 ータとしている。 $P_{m}(s)$ は規範モデルであり, 本論文 では簡単に加速度コントローラを構成するために，こ こに理想的な加速度コントローラを採用している。こ の規範モデル $P_{m}(s)$ の出力に制御対象の $P(s)$ の応答 を一致させるために，亚列補償要素 $H(s)$ 加制御対象 に補罆入力を加えることになる。従って，H(s)は制 御対象の応答を理想的な加速度コントローラの応答に 一致させるようにするので，制御対象を加速度コント

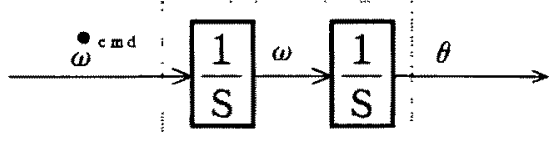

図 1 加速度コントローラの構成図

Fig. 1. Acceleration controller.

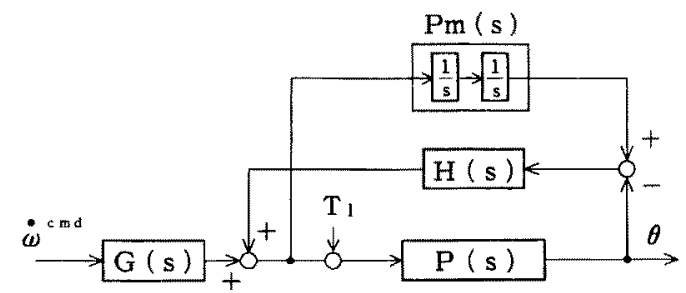

図 2 モデル追徒加速度制御系の構成図

Fig. 2. Model following acceleration control system.
ローラに変換させるための前置フィル夕 $G(s)$ はスカ ラ量の1でよいことになる。これより，図2のモデル 追従加速度制御系は，並列補償要素 $H(s)$ の構成を除 くと，その他の構造とパラメータは一意に決定される ことになる。

並列補借要素 $H(s)$ は，一般に規範モデルの逆シス テム $P_{m}^{-1}(s)$ と低域フィルタ $F(s)$ をカスケード結合 した系で構成される。図 2 に扔いて，規範モデルが 2 個の積分器で構成されるので，その逆システム $P_{m}^{-1}(s)$ は 2 階の微分系となり，低域フィルタ $F(s)$ は二次遅れ要素となる。この低域フィル夕 $F(s)$ の周 波数特性が，加速度コントローラを維持する周波数带 域を決めるので，設計者はなるへくく高い周波数帯域ま

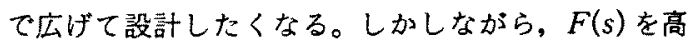
以周波数带域まて広げると，系全体の対雜音性や口バ スト安定性が難しくなるときが出てくる。このため， この低域フィルタ $F(s)$ は，実際に加速度コントロー ラを構成するときに，試行錯詔的に調整されることが しばしばである。

そこで本論文では，図 3 に示すように並列補偵要素 $H(s)$ に直列にファジィフィル夕 $F U(s)$ t插入して, 低域フィルタ $F(s)$ の構造を一意に決定することを提 案する。すなわち，低域フィル夕 $F(s)$ をデル追従 加速度制御系のソフトウェアのサンプリング周波数の $1 / 10$ 程度に応答する二次迤れ要素で構成し，試行錯 的な調整作業を直列に㨉入されたファジイフィル夕

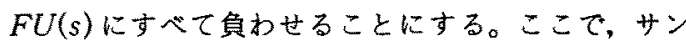
プリング周波数の1/10 程度とした理由は，理想的な 信号処理がサンプリング周波数の 1/10 程度までとみ なされるからである。このように，加速度コントロー ラの周波数特性の実現上の不都合をすべてファジィ フィルタ $F U(s)$ の設計で考慮したのて，寒現される 加速度コントローラのパラメータはファジィフィルタ

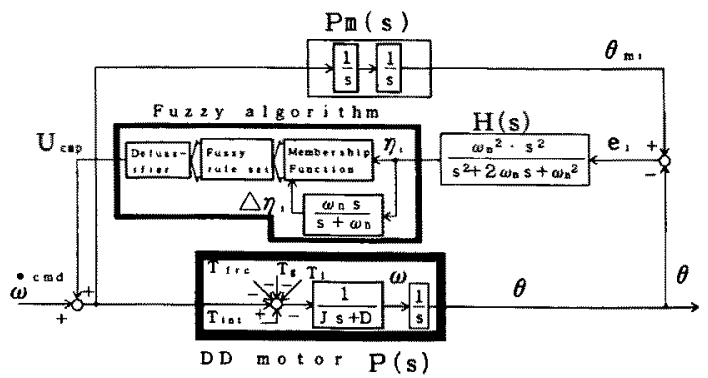

图 3 ファジィフィルタを用いたモデル追従 加速度制御系

Fig. 3. Model following acceleration control system using fuzzy filter. 
以外のすへてを一意的に定まることになる。

\section{3. ファジィフィルタの構成と弚の特性}

図3における加速度コントローラに使用されるファ ジィフィルタ $F U(s)$ のルゴリズムは,「IF〜, THEN〜」形式の 25 個のルールで構成されている。 ファジィフィルタ $F U(s)$ のアルゴリズムの入力は並 列補償要素 $H(s)$ の出力 $\eta$ とそのサンプリンク゚時間の

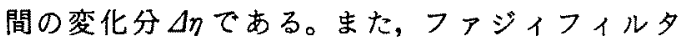
$F U(s)$ のルゴリズムの出力は, アクチュエータへ の操作量 $U_{\mathrm{cmp}}$ となる。このルールを以下に示す。

$$
\begin{aligned}
& \text { ルール } 1: \text { IF } \eta=P B, \Delta \eta=P B, \\
& \text { THEN } U_{\mathrm{cmp}}=P B \\
& \text { ルール } 2: \text { IF } \eta=P B, \Delta \eta=P S, \\
& \text { THEN } U_{\mathrm{cmp}}=P B \\
& \text { ルール } 25: \text { IF } \eta=N B, \Delta \eta=N B, \\
& \text { THEN } U_{\mathrm{cmp}}=N B
\end{aligned}
$$

このルールをまとめると，表 1 のようになる。表 1 において，これらのファジィアルゴリズムの前件部と 後件部の各々の值は, 制御対象と制御系を実現する装

表 1 ファジィフィルタのアルゴリズムのルール

Table 1. Fuzzy rule set of fuzzy filter.

\begin{tabular}{c|c|c|c|c|c|c}
\hline \multirow{2}{*}{} & & \multicolumn{6}{|c}{$\Delta \eta$} \\
\cline { 3 - 7 } & & $P B$ & $P S$ & $Z O$ & $N S$ & $N B$ \\
\hline \multirow{4}{*}{$\eta$} & $P B$ & $P B$ & $P B$ & $P M$ & $P S$ & $Z O$ \\
& $P S$ & $P B$ & $P M$ & $P S$ & $Z O$ & $N S$ \\
& $Z O$ & $P M$ & $P S$ & $Z O$ & $N S$ & $N M$ \\
& $N S$ & $P S$ & $Z O$ & $N S$ & $N M$ & $N B$ \\
& $N B$ & $Z O$ & $N S$ & $N M$ & $N B$ & $N B$ \\
\hline
\end{tabular}

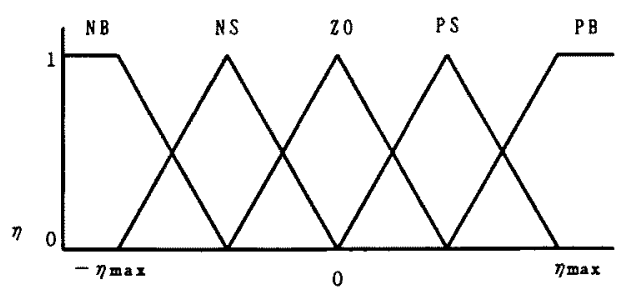

$\Delta \eta$

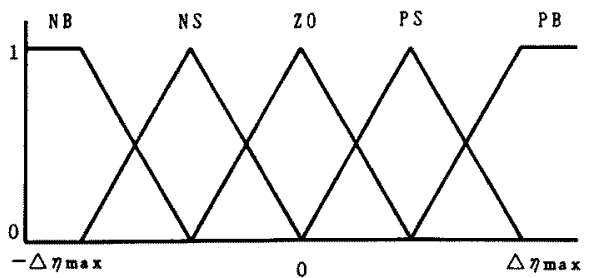

図 4 前件部のメンバジップ関数

Fig. 4. Membership function of fuzzy filter.
置の両者の特性を考慮した経験的知識に基づいて決定 することができる。ファジィフィルタFU(s)のアル ゴリスムの前件部には, 図4のような二等辺三角形の メンバシップ関数を採用している。各ルールの適合度 は,メンバシップ関数の重みを用いて(1)式のように 計算される。

$$
\left.\begin{array}{c}
\Omega_{11}=P B(\eta) \times P B(\Delta \eta) \\
\Omega_{12}=P M(\eta) \times P B(\Delta \eta) \\
\vdots \\
\Omega_{55}=N B(\eta) \times N B(\Delta \eta)
\end{array}\right\}
$$

本論文では，ファジィ推論の計算量を少なくしてサ ンプリング時間を短くするために，ファジィルールの 後件部をシングルトン形式で表現している。従って， ファジィフィルタ $F U(s)$ の出力は (2) 式の重み付け 平均式に上って算出される。

$$
U_{\mathrm{cmp}}=\frac{\Omega_{11 i} \times P B+\Omega_{12 i} \times P B+\cdots+\Omega_{55 i} \times N B}{\Omega_{11 i}+\Omega_{12 i}+\cdots+\Omega_{55 i}}
$$

提案するファジィフィルタ $F U(s)$ の応答特性の調 整は，後件部のパラメータを固定にして，前件部のパ ラメータ $\eta_{\max }$ と $\Delta \eta_{\max }$ のみで行うことにする。これ より,ファジィフィルタ $F U(s)$ 調整をより簡単に 行うことができることになる。アクチュエータの出力 には，必ず最大值が存在する。制御系の補償量がどん なに大きくても，実際にはある值に制限されてしま う。これより，ファジィフィルタのルールの後件部の $P B$ と $N B$ の值はアクチュエータの最大出力值かまた は定格出力值になる。後件部の $P B$ と $N B$ が定まる と, $P M, P S, N M, N S$ の值もある程度定まること になる。ここに技術者の経験的知識を導入すれば，後 件部の各值はアクチュエータの能力に応じた最適なゲ イン配分を行ったことになる。本論文では，そのように 後件部の各值を定めてファジィフィルタを構筑する。

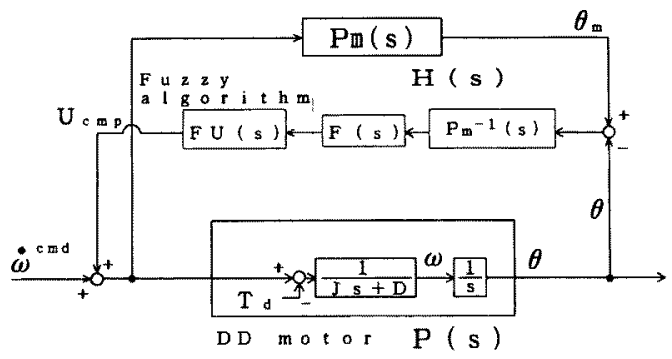

図 5 ファジィフィルタを用いたモデル追従加速度 制御系の構成

Fig. 5. Block diagram of model following acceleration control system using fuzzy filter. 
このファジィフィルタを用いたモデル追従加速度制 御系の構造を改めて図 5 に示す。図 5 において, 並列

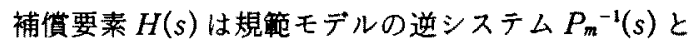
低域フィルタ $F(s)$ のカスタード結合で表し, 制御対 象のアクキュエー夕に印加される外力をまとめて $T_{d}$ で表す。これより，モデル追従加速度制御系は 2 入力 1 出力の系となるので, 出力 $\theta$ までの伝達特性を記 述すると(3)式のようになる。(3)式において, 規範 モデル $P_{m}(s)$ とその逆システム $P_{m}^{-1}(s)$ は相殺される ので，(3)式は(4)式のようにまとめられる。よっ て, 図 5 の構成図は図 6 の構成図に変換することがて きる。

$$
\left.\begin{array}{c}
\theta=\frac{P_{m}(S)\left[\dot{\omega}^{\mathrm{cmd}}-\left\{1-F U(S) F(S) P_{m}^{-1}\right.\right.}{\left[\delta ( S ) \left\{1-F U(S) F(S) P_{m}^{-1}\right.\right.} * \\
* \frac{\left.\left.(S) P_{m}(S)\right\} T_{d}\right]}{\left.\left.(S) P_{m}(S)\right\}+1\right]} \\
\delta(S)=\frac{P_{m}(S)-P(S)}{P(S)}
\end{array}\right\}
$$

$$
\theta=\frac{P_{m}(S)\left\{\dot{\omega}^{\mathrm{cmd}}-\{1-F U(S) F(S)\} T_{d}\right]}{\{\delta(S)\{1-F U(S) F(S)\}+1\}}
$$

図 6 と(4)式より制御対象のアクチュエータに加わ る外力の影響を抑えて，アクチュエータを加速度コン トローラにするためには，(5)式が成立すればよいこ とになる。更に，(5)式が成立するには，(6)式が成 り立てばよいことになる。

$$
\begin{aligned}
& 1-U(S) F(S)=0 \\
& U(S) F(S)=1
\end{aligned}
$$

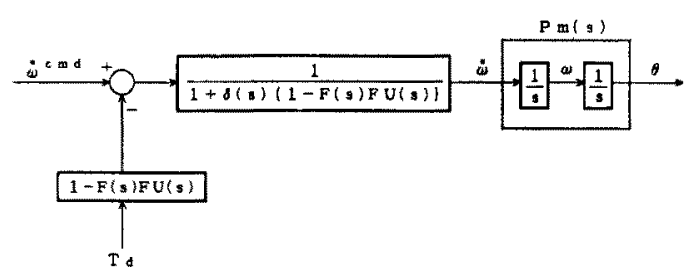

図 6 図 50 等価変換図

Fig. 6. Equivalent system of Fig. 5 .

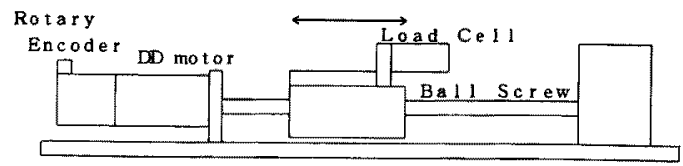

図 71 自由度マニピニレータの実験システム Fig. 7. Tested one-degree-of-freedom manipulator.
すなわち，ファジィフィルタ $F U(S)$ と低域フィル 夕F(s)のカスケード結合した系のゲインが1である ならば, 外力の影幚を完全に抑圧するロバストな加速 度コントローラを実現することができることになる。 本論文で提案するファシィフィルタは, 入出力の伝達

表 2 実験システムの仕様と定格

Table 2. Specification and rated value of tested system.

\begin{tabular}{l|c||c|l}
\hline Rated voltage & $100 \mathrm{~V}$ & Maximum torque & $7.14 \mathrm{~N} \cdot \mathrm{m}$ \\
Rated current & $3.8 \mathrm{~A}$ & $J$ & $4.08 \times 10^{-8} \mathrm{~N} \cdot \mathrm{m}$ \\
Rated torque & $0.44 \mathrm{~N} \cdot \mathrm{m}$ & $D$ & $0.0 \mathrm{~N} \cdot \mathrm{s} / \mathrm{m}$ \\
Maximum speed & $209.33 \mathrm{rad} / \mathrm{s}$ & & \\
\hline
\end{tabular}

表 3 人間が調整したファジィフィルタのパラメータ Table 3. Parameters of fuzzy filter tuned by human operater.

\begin{tabular}{cll}
\hline$\eta_{m a x}=2.0165 \times 10^{-2} \mathrm{rad} / \mathrm{s}^{2}$ & $\Delta \eta_{\mathrm{max}}=5.0000 \times 10^{-2} \mathrm{rad} / \mathrm{s}^{2}$ \\
\hline$P B=7.14 \mathrm{~N} \cdot \mathrm{m}$ & $P M=0.714 \mathrm{~N} \cdot \mathrm{m}$ & $P S=0.0714 \mathrm{~N} \cdot \mathrm{m}$ \\
$N B=-7.14 \mathrm{~N} \cdot \mathrm{m}$ & $N M=-0.714 \mathrm{~N} \cdot \mathrm{m}$ & $N S=-0.0714 \mathrm{~N} \cdot \mathrm{m}$ \\
\hline
\end{tabular}

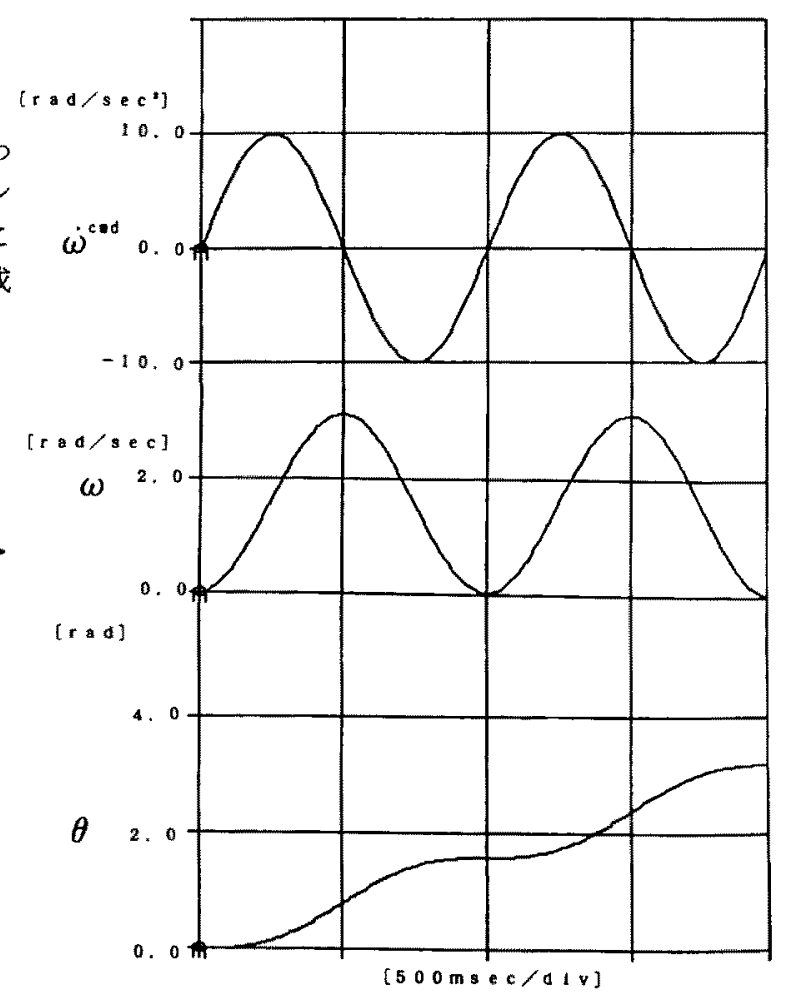

図 8 加速度指令に対する応答のシミュレーション 結果(人間がファジィフィルタを調整した場合)

Fig. 8. Numerical results of output response to sine curve acceleration command $\dot{\omega}^{\text {cand }}$. 
特性の定常ゲインが1である低域フィル夕になるよう に設計されるので（6)式の条件を满足することにな る。また，低域フィルタ $F(s) の$ 周波数带域は加速度 コントローラのソフトウェアのサンプリング周波数の 限界の带域になっているので,ファジィフィルタ $F U(s)$ の周波数特性によって加速度コントローラの 周波数特性を所望のものにすることになる。

そこて，提案する加速度コントローラの有奻性を確 認するために，図 7 に示す 1 自由度マニピュレータの

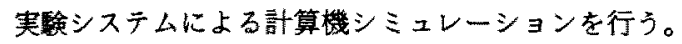
実駼システムは、ボールネジよってDDモータの回 転トルクを直進方向の力に変換させている。実験シス テムのアタキュエータの定格と仕様は表 2 に示す。ま た,このときの加速度コントローラのサンプリング時

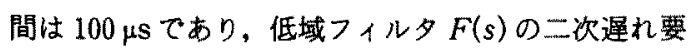
素の固有提動数は $1,000 \mathrm{rad} / \mathrm{s}$ である。

まずモデル追徒加速度制衔系のファジィフィルタ $F U(s)$ を試行錯䛠的に調整する。すると，表 3 に示 すファジィフィルタ FU(s)が楎成される。次に，こ のファジィフィルタ $F U(s)$ を用いてモデル追従加速 度制御系の加速度指令 $\dot{\omega}^{\mathrm{cmd}}$ に対する DD ータの位 置 $\theta$ と速度 $\omega$ の時間応答特性を調べる。その結果を 図8に示す。図 8 の結果により,ファジィフィルタを 用いたモデル追従加速度制御系が加速度指令 $\dot{\omega}^{\mathrm{cmd}}$ に

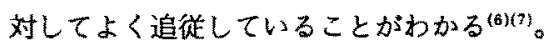

\section{4.ファジィフィルタの自動調氆アルゴリズム}

本猃文では，表 1 に示されるファジィフィルタ

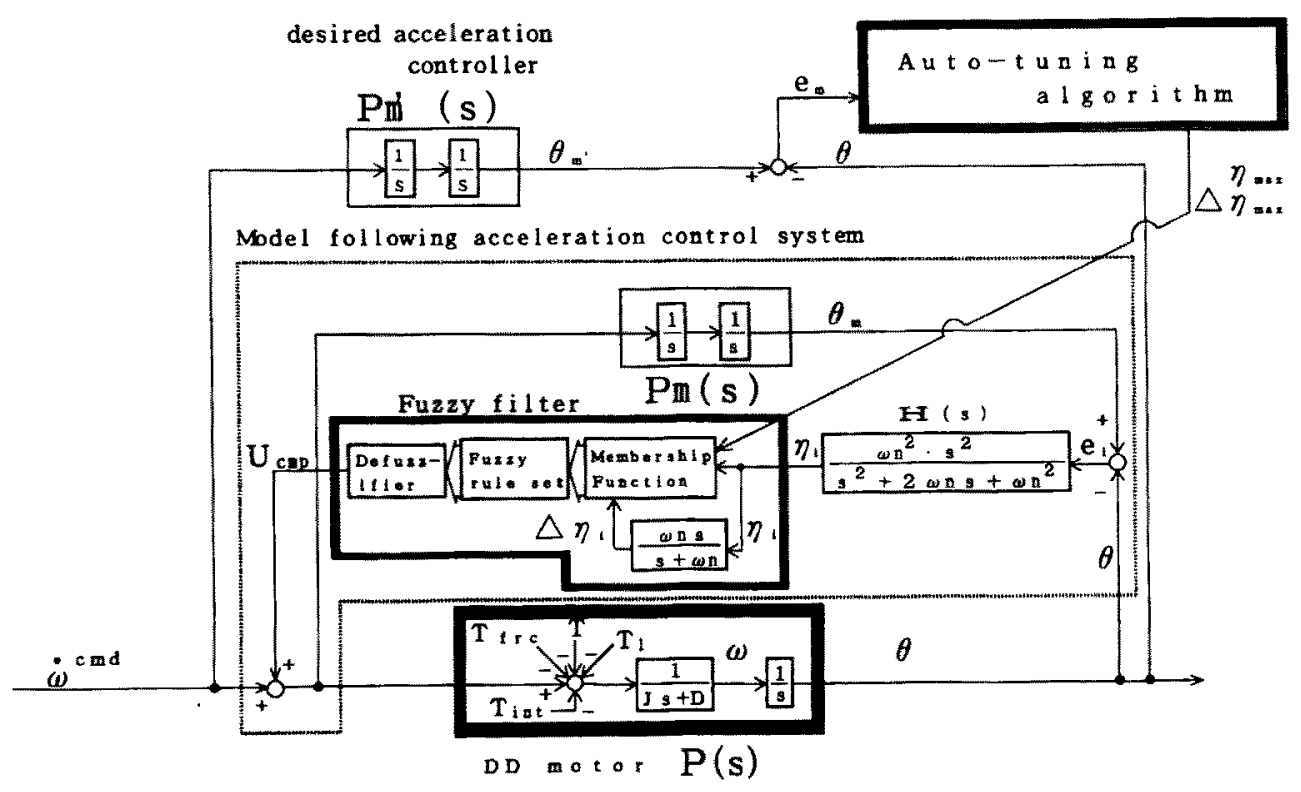

図9オートチューニングファジィフィルタによる加速度コントローラの構成図

Fig. 9. Model following acceleration control system using auto-tuning fuzzy filter.

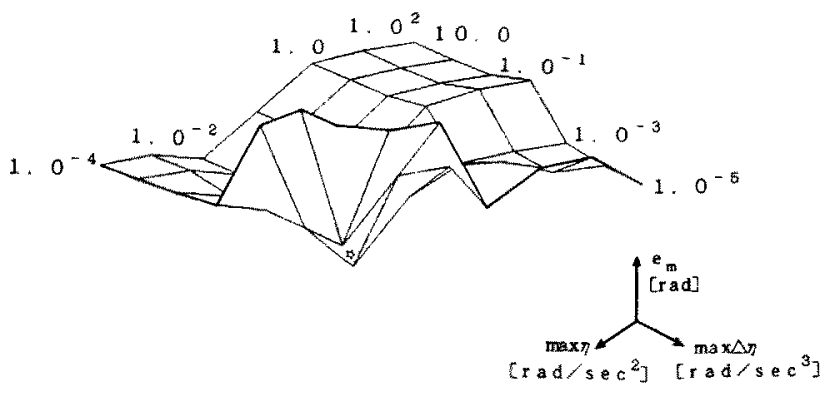

図 10 二剰誤差平均 $e_{m}$ とメンパシップ関数の底辺の長さとの関係

Fig. 10. Relation to $\varepsilon_{m}, \eta_{\max }$ and $\Delta \eta_{\max }$. 
$F U(s)$ のアジィルールを，ロボットマニピュレー タのアクチュエータのいかんにかかわらず一意に決定 している。ファジィルールの各パラメータの值は, ア クチュエータの最大出力かまたは定格出力の值を $P B$ と $N B$ の值にすることにより, 順に $P M, P S, N M$, $N S$ の值が適当に配分されることになる。従って，フ アジィフィルタ $F U(s)$ の特性を調整する䉪所は, 図 4 に表されるメンバシップ関数の二等辺三角形の底辺 の長さとなる。

一般に, 図 4 のメンバシップ関数の底辺の長さを小 さくすると，周波数特性が高帯域まで伸び即応性が増 すが，逆に小さくし過ざると振動的になる。また，底 辺の長さを大きくすると, 周波数特性が高帯域まで伸 ばせなくなるので対雑音性は良いが, 逆に大きくし過 ぎると即応性が鈍くなる。そこで，本論文ではこの特 長を利用して，ファジィフィルタ $F U(s)$ をオートチ ューニングアルゴリズムによって目動的に調整するこ とを試みる。

オートチューニングアルゴリズムを作製するため に,ファジィフィルタを用いたモデル追従加速度制御 系の応答性能とメンバシップ関数の底辺の長さの関倸 を図 9 に示すシステムで調べる。ここで，理想的な加 速度コントローラ $P_{m}{ }^{\prime}(s)$ の出力 $\theta_{m}$ と実際のアクチュ エータ $P(s)$ の出力 $\theta$ の差の二乗誤差平均値 $e_{m}$ を (7)式に定義し，この $e_{m}$ と各メンバシップ関数の底 辺の長さ $\Delta \eta_{\max }$ と権的関係を, 定量的に図 10 のよ うな三次元のグラフで示す。二乗誤差平均值 $e_{m}$ は, $P_{m}^{\prime}(s)$ と $P(s)$ に正弦波の加速度指令 $\dot{\omega}^{\mathrm{cmd}}$ をえて, その 1 周期を 100 分割したときのそれぞれのデータか ら算出している。図 10 の定量的データは，図 7 の実 験システムに $0.5 \mathrm{~Hz}$ の正弦波の加速度指令值 $\dot{\omega}^{\mathrm{cmd}}$ を与えたときのものである。また図 100 的の筬所は, 先に設計者が試行錯誤的に求めたファジィフィルタを 示している。

$$
\begin{aligned}
& e_{m}=\frac{1}{k} \times \sum_{i=1}^{k}\left\{\theta_{m}{ }^{\prime}-\theta\right\}_{i}^{2} \cdots \cdots . . \\
& \text { ただし, } k=100 \text { (データ数 })
\end{aligned}
$$

図10の結果より, 二乗誤差平均值 $e_{m}$ は設計者の 調整した方の箇所に向かって単調減少になっているこ とがわかる。そこで本論文では, 二乗誤差平均值 $e_{m}$ が最小となるようなファジィフィル夕を探索するアル ゴリズムを形成することにする。図 10 の三次元グラ フは, 制御対象のアクチュエータによって変動するこ とが予想されるが, DD モータやサーボモー夕の場合 にはほとんど図10のような単調減少の傾向を示すこ とがシミュレーションによって得られている。
図10のような数式で記述できない単調隇少の探索 問題を解く方法には，シンプレックス法が一般的であ る(8)。シンプレックス法はシンプレックスという多角 形を用いて，その頂点の高さから逐次高さの低い地点 ヘシンプレックスを移動させていく方法である。本論 文では, 調整するパラメータが $\Delta \eta_{\max }$ と $\eta_{\max }$ の 2 変 数であるため、シンプレックスに三角形を採用してい る。図 11 に自動調整アルゴリスムで採用している三 角形の基本的な移動方法を示す。提案する自動調整厂

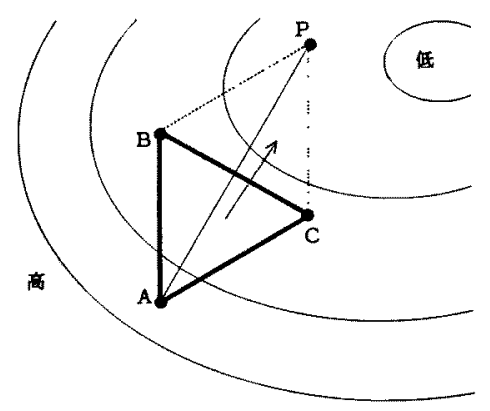

(a) シンプレックスの移動

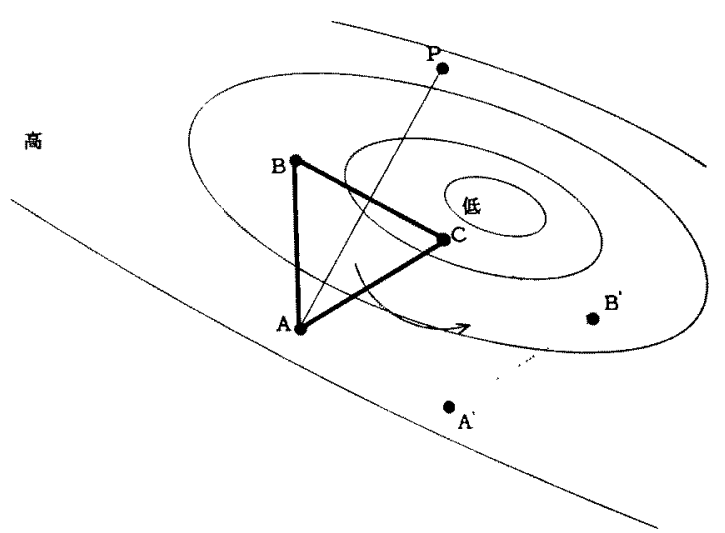

(b) シンプレックスの回転

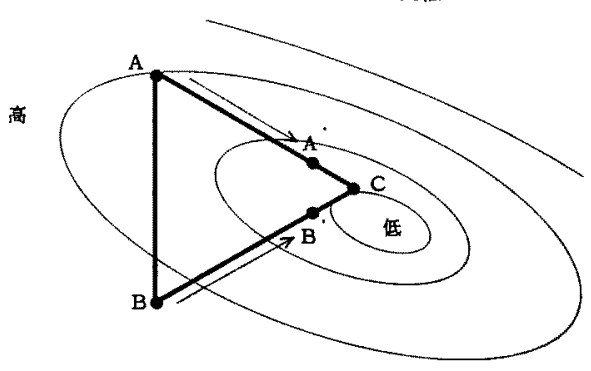

(c) シンプレッタスの綰小

図 11 自動調整アルゴリスムにおける シンプレックスの移動方法

Fig. 11. Moving method of simplex in auto-tuning algorithm. 


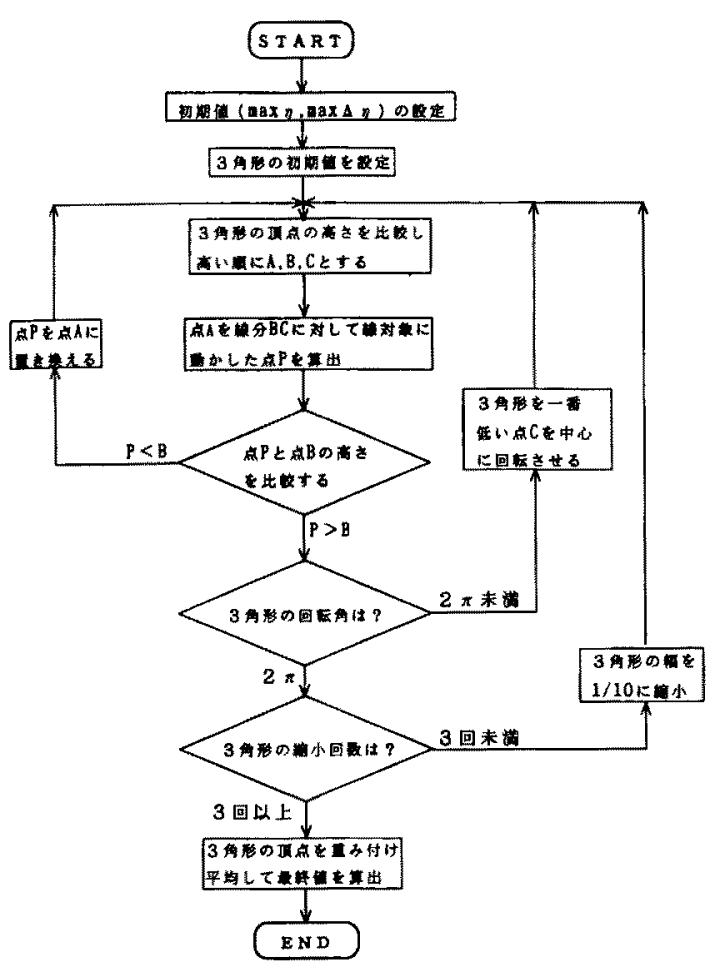

図 12 自動調整アルゴリスムの流れ図

Fig. 12. Flowchart of auto-tuning algorithm.

ルゴリズムは图11の移動方法を組合せて, 三角形を 図 12 の流れ図に徒って，二乗酷差平均值 $e_{m}$ の最も 小さい領域へ移動させていく。そして，自動調整アル コリズムが最終的に収束すると， $\Delta \eta_{\max } と \eta_{\max }$ は最 終的に得られた三角形の頂点の重み付け平均值によっ て网定される。

加速度コントローラがこの自動調整アルゴリズムに よって所望の周波数特性をもつためには,ファジィフ イル夕 $F U(s)$ を調整するときの加速度指令 $\dot{\omega}^{\mathrm{cmd}}$ とし て，所望の周波数特性の正弦波の加速度指令值 $\dot{\omega}^{\mathrm{cmd}}$ を与えればよいことになる。すなわち，加速度コント ローラの周波数特性も，自動調整アルゴリズム孛動作 させるときの加速度指令值 $\dot{\omega}^{\mathrm{cmd}}$ の周波数によって同 時に一意的に決定されることになる。

提案する自動調整アルゴリズムの有効性を計算機シ ミュレーションによって確認する。シミュレーション では，まず図 7 実験システムのモデル追従加速度制 御系のファジィフィル夕 $F U(s)$ を, 自動調整アルゴ リズムによって調整する。このときの加速度指令值 $\dot{\omega}^{\mathrm{cmd}}$ は， $0.5 \mathrm{~Hz}$ の周波数の正弦波である。ファジィ

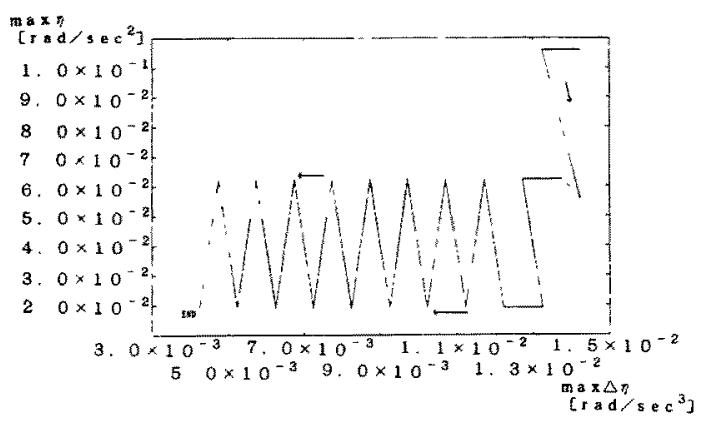

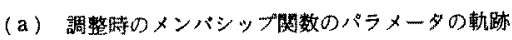

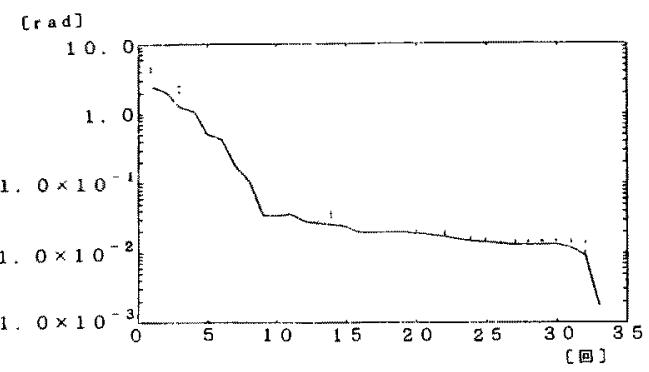

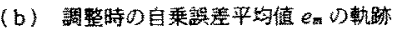

図 13 自動調整アルゴリズムの シミュレーション結果

Fig. 13. Tuning locus of auto-tuning algorithm in numerical simulation.

表 4 自動調整アルゴリズムで調整された ファジィフィルタ

Table 4. Parameters of auto-tuning fuzzy filter in simulation.

$\eta_{\max }=1.9645 \times 10^{-2} \mathrm{rad} / \mathrm{s}^{2} \quad \Delta \eta_{\max }=4.1961 \times 10^{-2} \mathrm{rad} / \mathrm{s}^{2}$

$P B=7.14 \mathrm{~N} \cdot \mathrm{m} \quad P M=0.714 \mathrm{~N} \cdot \mathrm{m} \quad P S=0.0714 \mathrm{~N} \cdot \mathrm{m}$

$N B=-7.14 \mathrm{~N} \cdot \mathrm{m} \quad N M=-0.714 \mathrm{~N} \cdot \mathrm{m} \quad N S=-0.0714 \mathrm{~N} \cdot \mathrm{m}$

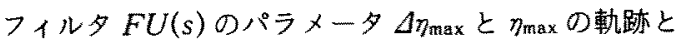
自乗誤差平均值 $e_{m}$ の軌跡を図 13 に示し, 表 4 に最

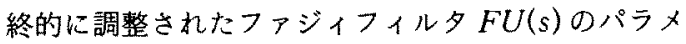
一タの值を示す。また，計算機シミュレーションは図 14 に示す。この結果より, 提案する自動調整アルゴ

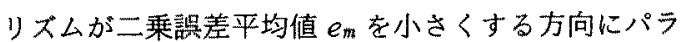
メータを調整していることが確認できる。更に，表 4 と表 3 とを比較すると、ファジィフィルタ $F U(s) の$ パラメータがほとんぞ同じ值に収束しているので, 困 8 と図 14 のシミュレーション結果も同じ応答になっ てことがわかる。よって，提案する白動調整アルゴリ ズムが，人間による試行錯詰的謂整とほほ同様の調整 


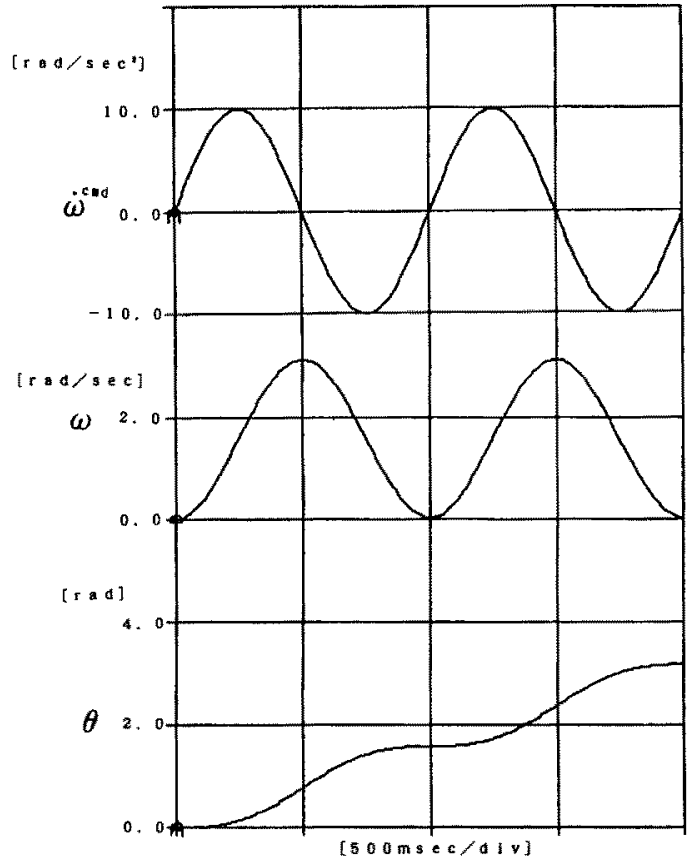

図 14 加速度指令に対する応答のシミュレー ション結果(オートチューニングファジィ フイル夕を用いた場合)

Fig. 14. Numerical results of output response to sine curve acceleration command $\dot{\omega}^{\text {cmd }}$.

を行えることが確認される。

\section{5. 実験結果}

次に，図15に示される軌跡追従制御系の実験を行 って，自動調整アルゴリズムによって調整された加速 度コントローラの有效性を実際に確諗する。軌跡追従 制御系は（8)式の伝達関数で表現されるように，位 置・速度 ・加速度の各々の指令值に対してマニピュレ ータが位相遅れを生じないように追従させる制御系で ある。実験システムのハードウェアシステムは図 16 にホす。オートチューニングファジィフィルタを用い たモデル追従加速度制御系，および軌跡追従制御系は DSPのアセンブリ言語で寒現されている。そのサン

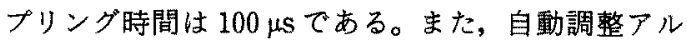
ゴりズムはマイクロプロセッサ(i 80286)上のC言語 で実現されている。

図 17 に自動調整アルゴリズムによって調整された ときのファジィフィルタ $F U(s)$ のハラメータと二乗 詔差平均值 $e_{m}$ の軌跡を示す。最終的に自動調整アル ゴリズムによって調整されたパラメータを表 5 に示

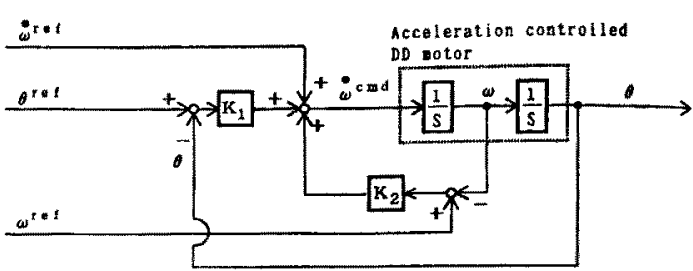

图 15 軌跡追従制御系の構成図

Fig. 15. Continuous path tracking control system.

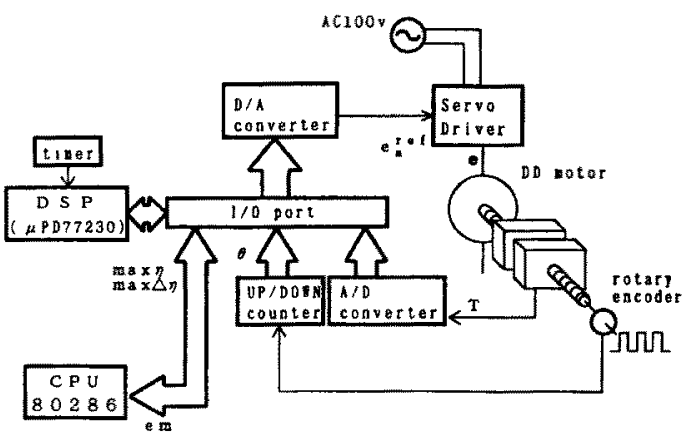

図 16 実験システムのハードウェア

Fig. 16. Hardware of tested system.

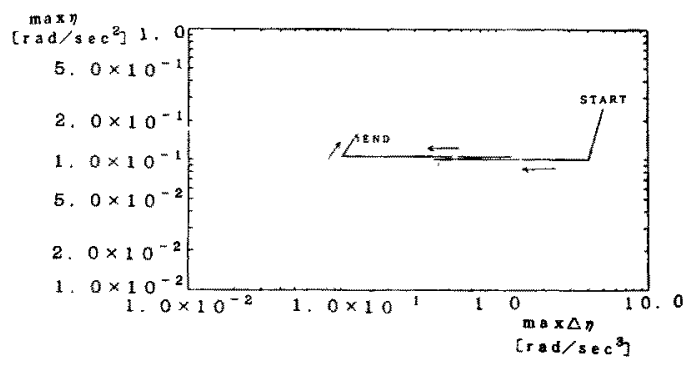

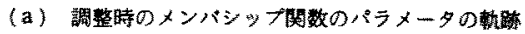

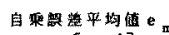
$\left[\begin{array}{ll}\mathrm{a} & \mathrm{d}]\end{array}\right.$

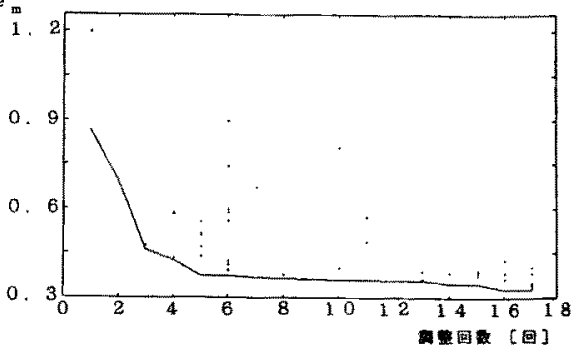

(b) 調整時の二乗誤差平均值 $e_{m}$ の㭳䟽

図 17 自動調整アルゴリズムの実験結果 Fig. 17. Tuning locus of auto-tuning algorithm in experiment. 
表 5 自動調整アルゴリズムで調整された実験の

$$
\text { ファジィフィルタ }
$$

Table 5. Parameters of auto-tuning fuzzy filter in experiment.

\begin{tabular}{cll}
\hline$\eta_{\max }=1.2737 \times 10^{-2} \mathrm{rad} / \mathrm{s}^{2}$ & $\Delta \eta_{\max }=1.1640 \times 10^{-1} \mathrm{rad} / \mathrm{s}^{2}$ \\
\hline$P B=7.14 \mathrm{~N} \cdot \mathrm{m}$ & $P M=0.714 \mathrm{~N} \cdot \mathrm{m}$ & $P S=0.0714 \mathrm{~N} \cdot \mathrm{m}$ \\
$N B=-7.14 \mathrm{~N} \cdot \mathrm{m}$ & $N M=-0.714 \mathrm{~N} \cdot \mathrm{m}$ & $N S=-0.0714 \mathrm{~N} \cdot \mathrm{m}$ \\
\hline
\end{tabular}

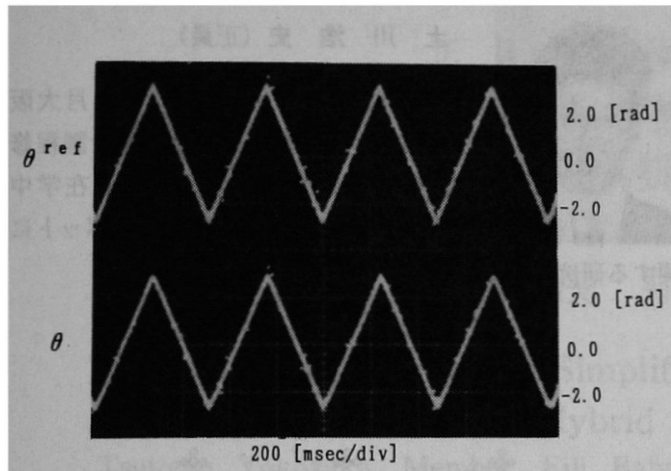

(a) 従来のモデル追従加速度制御系

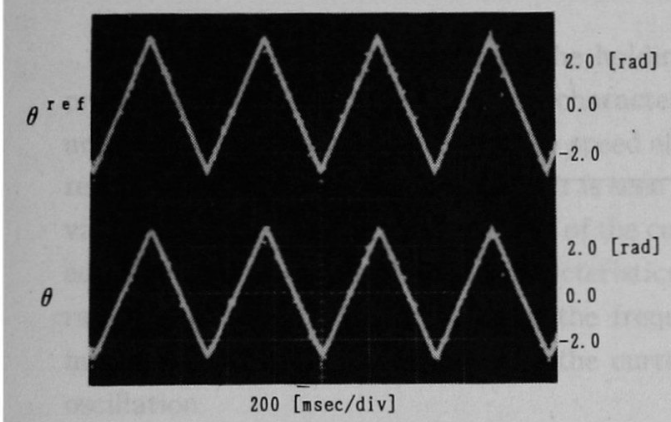

(b) ファジィフィルタを用いたモテル追促加速度制卸系 (人間がファジィフィルタを調整した場合)

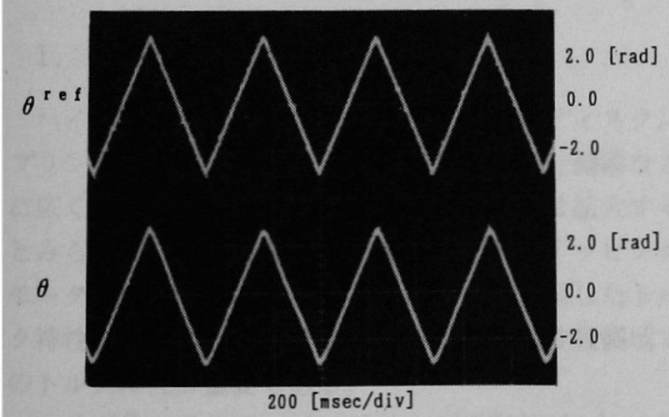

(c) ファジィフィル夕を用いたモデル追従加速度制御系 (オートチューニングファジィフィルタ)

図 18 軌跡追従制御の実験結果

Fig. 18. Experimental results of continuous path tracking control.
す。実験結果より, シミュレーションと同様に, 二乗 誤差平均值 $e_{m}$ が小さくなる方向にファジィフィル夕 のパラメータを調整していることがわかる。このとき の加速度コントローラの低域フィルタ $F(s)$ の二次遅 れ要素の固有振動数も $1,000 \mathrm{rad} / \mathrm{s}$ である。

実験結果は図 18 に示す。実験は位置指令值 $\theta^{\text {ref }}$ と して三角波状の信号を入力したときの 1 自由度マニピ ユレータの位置 $\theta$ を計測している。図 18 には, 規範 モデルに制御対象のノミナル值を用いた従来のモデル 追従加速度制御系での結果と, 人間が試行錯誤的に調 整したファジィフィルタを用いたモデル追従加速度制 御系の結果と, 更に自動調整アルゴリズムによって調 整されたファジィフィルタを用いたモデル追従加速度 制御系の結果を示している。ただし, 従来のモデル追 従加速度制御系の低域フィルタ $F(s)$ の二次遅れ要素

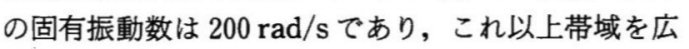
げることは無理だった。

実験結果より,どの加速度コントローラにおいて も, 制御対象の 1 自由度マニピュレータの出力 $\theta$ が 指令値 $\theta^{\text {ref }}$ に完全に追従していることがわかる。こ れより, 自動調整アルゴリズムが適切にファジィフィ ルタ $F U(s)$ のパラメータを調整していることがわか る。

また, 制御対象のアクチュエータのノミナル值に 2〜3 倍の変化が存在しても図 17 と図 18 の実験結果 と同じようになった。これは, 規範モデルに理想的な 加速度コントローラを採用しているので最初から規範 モデルと制御対象のモデル化誤差がかなり大きくなる ため, 実際に想定されるパラメー夕変動に対してほと んど影響がないものと考えられる。

\section{6. ま と め}

本論文では, アクチュエータのパラメータのノミナ ル值をいっさい必要としないで, 自動的に所望の周波 数特性をもつ加速度コントローラを実現する手法を提 案した。提案する加速度コントローラは, 制御対象の 構造やパラメータの情報をあらかじめ知っておく必要 がない。また, 加速度コントローラの周波数特性を決 定する作業をすべてオートチューニングファジィフィ ル夕に集約させているので, 設計者は試行錯誤的作業 や経験的知識を全く必要とせずに加速度コントローラ を構成できることが, 実験とシミュレーションによっ てわかった。

本論文が、マニピュレータもモーション制御におい てご参考になれば幸いである。

(平成 4 年 4 月 13 日受付, 同 4 年 9 月 3 日再受付) 


\section{文献}

（1）駒田・村上・大西：「加速度に基づく多自由度ロボットの力 フィードバック制御」, 電学論 D, 109,325(平元-5)

（2）松田・大石：「位置情報たけを用いたDSPによる加速度制 御系」, 同上 D, 110, 101(平 2-2)

（3）大石・松田：「DDアクチュエータのカとコンプライアンス のロバスト制御」，同上 D, 110，1133(平 2-11)

(4) C. H. An, C. G. Atkeson \& J. M. Hollebach: Model-Based Control of a Robot Manipulator (1988) The MIT Press

(5) J. J. Craig: Introduction to Robotics Mechanics \& Control (1986) ADDISON WESLEY

（6）土川・片岡・大石・荻野：「オートチューニングファジィ加 速度コントローラの構成法」, 電気学会産業計測制御研資, IIC- $91-13$, p. 1(平 3 )

(7) K. Ohishi, H. Tsuchikawa \& H. Kataoka: "Motion Control Based on Auto-tuning Fuzzy Acceleration Controller", Proc. of IEEE/IES AMC '92, p. 369

（8）志水：システム最適化理論(昭 51)コロナ社

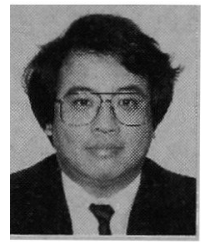

\section{大石潔（正員）}

昭和 32 年 10 月生。 61 年 3 月慶応義 塾大学大学院工学研究科博士課程修了。 同年 4 月大阪工業大学電気工学科講師。 平成元年同大学助教授, 現在に至る。工
学博士。1986 年 IEEE/IECON '85 Outstanding Paper Award。主として, 電動機制御, ロボット,ファジィ制 御に関する研究に従事。IEEE, 計測自動制御学会, シス テム制御情報学会, 日本ロボット学会, 日本ファジィ学 会, 日本機械学会会員。

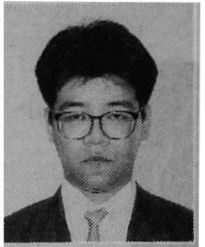

土川浩 史 (正員)

昭和 42 年 6 月生。平成 4 年 3 月大阪 工業大学大学院工学研究科修士課程修 了。同年 4 月新日本製鐵入社。在学中 は, 主としてファジィ制御, ロボットに 関する研究に従事。
280

20

28 